\title{
EXPLORING BEGINNING ENGLISH LANGUAGE TEACHERS' BELIEFS OF TEACHING READINESS IN THE PUBLIC SECTOR SCHOOLS IN PUNJAB
}

\author{
Ali Raza \\ Research Scholar, \\ Department of Sciences \& Humanities, National University \\ of Computer and Emerging Sciences Lahore, \\ Punjab, Pakistan \\ Email: razzwattoo@gmail.com \\ Zahida Mansoor \\ Assistant Professor, \\ Department of Science \& Humanities, National University \\ of Computer and Emerging Sciences, \\ Punjab, Pakistan \\ Email: zahida.mansoor@nu.edu.pk

\section{Umer Ameem} \\ Research Scholar, \\ Department of Sciences \& Humanities, National University \\ of Computer and Emerging Sciences, \\ Punjab, Pakistan \\ Email: umerameem@gmail.com
}

\begin{abstract}
The study aims to explore beginning English language teachers' beliefs about their readiness for teaching in the public sector schools in Punjab. The change from the educational institution to the classroom proves to be unsettling for the beginners and the feeling of being prepared well for the profession does not seem to be present when they attempt to advance their teaching practices in new environments. The study employs quantitative approach to gain the individualized perceptions of beginner teachers' readiness for teaching through a self-reported survey questionnaire. 30 beginning English language teachers whose experience ranged from 1-4 years were taken as sample using purposive sampling technique. The findings reveal that majority of the beginning language teachers were not in readiness with regard to applying techniques for teaching different language skills such as speaking, listening, writing and reading. They also lacked expertise in planning lesson for differentiated learner style, lesson delivery and using appropriate assessment tools to assess learners'
\end{abstract}


performance. The study concludes that the initial training programs should enable beginner English language teachers to acquire these skills and apply new teaching methodologies in the real classroom environment. The results may lack generalizability. Therefore, researchers are encouraged to conduct a study in a different context in order to extend the scope of results. This paper fulfils an identified need to study how the beginner teachers can prepare themselves for the challenges in their initial teaching years.

\section{KEYWORDS}

Beginning teachers; readiness; beliefs; Public sector Schools; Teaching

methodologies

\section{INTRODUCTION}

A beginner teacher can be anyone who is teaching for the first time or just arrives in a new context (Farrell, 2009). The debate on the number of years of teaching necessary to end the beginning stage is ongoing with some defining beginner teachers as those with not more than five years of teaching experience (Kim \& Roth, 2011). While, others declare that teachers with two years or less teaching experience qualify as beginners (Haynes, 2011). However, these experiences may vary depending on the contexts, schools, and persons (Carre, 1993). The beginners usually go over myriad emotions including anxiety, frustration and self-doubt when they start their careers.

Teachers' readiness for their future occupation is conventionally measured by the quality of the education achieved and the pre- service training, explains (Woolfolk Hoy $\&$ Spero, 2005). But these experiences are often inadequate, as the complex demands of their work are not attended to in their college education and the subsequent induction training (Caspersen \& Raaen, 2014). In addition, Kee (2012) points out that the training program features should play a defining role in the state of readiness of the beginning teachers. In order to meet the expectations that they would be prepared in terms of obtaining essential pedagogic and classroom skills including awareness of classroom management, using instructional techniques, teaching subject material and evaluating students' performance.

In English language teaching, teachers prove to be an effective factor crucial to students' learning and achievements (Hammond, 2003). Shafie and Nayan (2010) describe the teachers' roles as knowledge transmitters, curriculum assessors, course planner and students' assessors in the educational setting. Being a teacher has its own impediments, and with the increasing responsibilities and expectations the teaching profession becomes more challenging in the case of beginning teachers (Graham \& Phelps, 2003), who have yet to gain the experience teaching different subjects (Belatrech, 2018). 
Teaching profession becomes more challenging in the case of beginners in non-English speaking countries particularly when it includes preparing them to apply fruitful teaching methodologies (Schmidt, 2008) and becoming a teacher expands its needs to include the qualities such as flexibility, innovation and bringing about the changes; leadership roles and implications for self-development (Brandenburg, 2008). In the classroom environment, usually the new teachers don't feel convincingly ready for the challenges they face during the initial years (Smith \& Ingersoll, 2004). Therefore, the teaching profession needs to be practiced properly in terms of lesson planning, classroom management, teaching language skills and assessing learners' performance (Meddour, 2017).

For teachers the initial year experiences in their careers prove to decisive in determining their future presence in the teaching community. Although, the public sector school teachers receive training on new teaching methodologies under various educational reforms. Yet, despite the educational qualification and professional training (AL-Hazmi, 2003) the beginning teachers do not feel adequately prepared when they attempt to develop their teaching practices in the diverse traditional teaching and learning environments of the public sector schools.

The study highlights the skills that the beginners are expected to acquire during their induction program. The findings of the study may prove to be vital in developing programs or strategies that would ease the beginning teachers' problems. It also informs the policy makers in the developing policies.

\section{Conceptual Framework}

The study used the framework "European Portfolio for Student Teachers of Languages" (EPOSTL, 2007) to explore beginning language teachers' beliefs about their readiness for teaching and their early challenges. The framework encompasses an overview of the skills needed by teachers and it serves as a tool for self-assessment for the student teachers and the practicing teachers. It helps the teachers to prepare for their teaching profession in the variety of contexts.

This research was delimited to explore beginning language teachers' readiness for teaching. For this purpose, beginning English language public sector secondary school teachers whose experience ranged from 1-4 years were selected as sample in the Punjab province.

\section{LITERATURE REVIEW}

Teachers likely to involve more in the jobs and carry them out effectively when they feel capable and self-assured to carry out their profession as teachers (Bandura, 1995). Baker (2002) outlines that in the field of pre-service teacher education, teachers are 
expected to be more prepared in executing teaching practices when they have sufficient knowledge to create a supportive environment for the learners. Teaching readiness helps teachers to design teaching methodologies systematically and implement teaching goals more effectively. The early period of teaching is usually challenging for teachers of different subjects (Ouma et al., 2013). The significance of teachers' readiness for the teaching profession seems to be an indisputable need. Teachers of new age need to be prepared with competencies which used to be inconceivable to most experts in the field twenty years ago. Change, although vital and inevitable, is never easy (Straková, 2015).

Becoming a teacher begins with an induction period during and an effective induction program needs to have a clear connection with the teaching in the real classroom environment so that the beginners could feel well prepared in order to combat the challenges they might come across during their first years when they undertake their teaching profession. The reason why beginning teachers do not feel themselves prepared for the teaching profession is that their pre-service teacher preparation programs and in-service teacher development are not affiliated (Farrell, 2012). The teacher education program carries utmost importance as it prepares teachers before they enter the profession. Teacher preparation is considered responsible for the success of schooling for educating the future teachers. It can also be understood that the teacher education is under the limelight as described by Ben-Pretz (2001): "much of the perceived failure of schooling is attributed to teachers who are thought to be ill prepared for their task because teacher education is deficient". For that particular reason, many efforts should be invested in improving the quality of the training programs that prepares the qualified teachers with necessary knowledge and the teaching skills.

Meddour (2017) discussed that the beginning teachers need to have pre-service teacher training along with their studies in which fundamental components of teaching need to be practiced and replicated especially lesson planning, classroom management and teaching language skills. Beginning language teachers' uncertainties of dealing with learners' discipline problems and preparing for lessons from a textbook and delivering the lesson should be catered.

While, Chaco'n (2005) outlined that the beginning language teachers receive insufficient training before they undertake their profession. The study concluded that the English language teachers require satisfactory preparation to acquire innovative techniques related to grammar, reading, writing, speaking and listening so that they may feel prepared enough to build a strong sense of making use of these acquired language skills not only for motivating and engaging learners, but also for designing instructional strategies for the better learning of the students. 
Similarly, Alharbi (2011) in his study, underlines skills such as lesson preparation, lesson delivery, classroom management and various other teaching methods that the English language teachers do not possess initially before undertaking their profession. Hussain et al., (2018) also emphasize beginners to have clear idea about lesson planning, classroom management and applying innovative teaching approaches in the classroom.

Managing a classroom is essential in order to create an environment that helps in keeping and maximizing the attention of learners during a lesson, however, the new teachers usually express their qualms about creating a learner friendly classroom environment, deal with disorderly learners and maintaining classroom discipline (Evertson \& Weinstein, 2006). Often claiming that the initial training programs do not prepare them with the much needed basic principles and the skills related to classroom management. Likewise, Fantilli and McDougall (2009) also add, that the beginners lack skills such as managing the classroom, obtaining instructional material and resources, lesson planning, organizing appropriate lesson content for different learners, assessing students' performance and evaluating their progress when they attempt to develop their practices.

In Pakistan, the development of the teachers who are expected to transform the life in school for the learners enabling them to become independent individuals, capable of critical and innovative thinking is seen as a daunting task (MoE, 2009). The teachers usually teach the way they were taught adhering to the traditional teaching practices, and usually reported to have neither the commitment nor the motivation for teaching. The teachers do not seem to have the opportunities to question their own views and understanding about the various educational issues in this form of pedagogy and one of the key uncertain blocks in the way of change is an obvious gap between teachers' supposed ideas and their actual practices (Siddiqui, 2010).

\section{RESEARCH OBJECTIVE}

1. The study attempts to explore the beliefs of the beginning teachers about their readiness for teaching in the public sector schools in Punjab.

\section{RESEARCH QUESTIONS}

1. What are the perceptions of the beginning English language teachers about their readiness for teaching in public sector schools in Punjab?

\section{RESEARCH METHODOLGY}

The study explored the beginning English language teachers' beliefs of teaching readiness. A quantitative approach was used in order to obtain the individualized perspectives of the beginning English language teachers' readiness for teaching in the 
public sector schools in Punjab. The current study uses the "European Portfolio for Student Teachers of Language" (EPOSTL), as the framework underpinning the exploration of the beginning language teachers' opinions of their teaching readiness. EPOSTL enables teachers to reflect on the attainment of skills in their early teaching careers, assisting them to contemplate on their acquisition of knowledge and necessary expertise needed to teach language. It helps in assessing and checking their development and document their experiences in a variety of contexts (Newby, 2007).

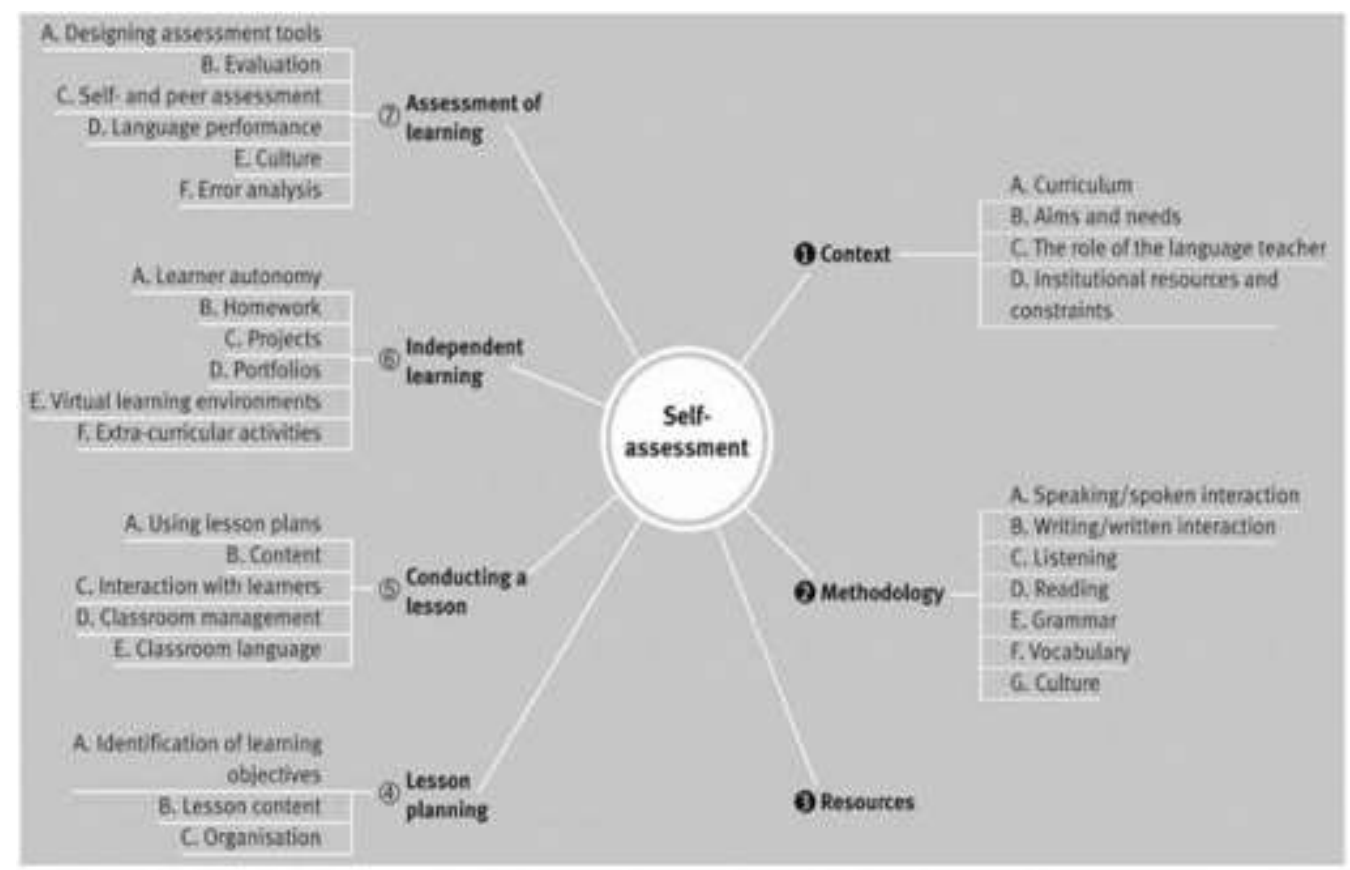

Figure 1: Grouping of the reflective descriptors (EPOSTL)

The tool provides a number of reflective skills which are grouped into seven main categories signifying areas where teachers require knowledge and skills in order to make choices related to teaching. On the basis of these descriptors, beginning English beginning English language teachers' beliefs of their teaching readiness were explored as one of the objectives of the current study aimed to explore their perceptions of teaching readiness as the initial years of their career are crucial in determining their future presence in the teaching community.

For the purpose of the study, the target population was the beginning English language teachers teaching in the public sector in the Punjab. Teachers whose experience ranged from one year to four years were selected in order to meet the objectives of the study 
as there seems to be no agreement on how many years of teaching are needed to end the beginning stage. 30 beginning English language teachers teaching at different public sector schools were selected through purposive sampling technique. Records of new teachers teaching in public sector schools with 1 to 4 years of teaching experience, was gathered from Programme Monitoring \& Implementation Unit (PMIU) Punjab.

In this research study, a questionnaire was developed for the beginning teachers who are teaching English as a second language in the public sector secondary schools in Punjab. The survey questionnaire was developed in line with the EPOSTL conceptual framework (Newby, 2007), Which includes the areas such as teaching context, methodology, resources, lesson planning, conducting a lesson, independent learning and assessment of learning that are necessary to teach English language. Each area has further sub categories which are comprised of the skills that the beginning language teachers need to have when they attempt to develop their teaching when they undertake their teaching profession. The questionnaire was adapted taking into account all the main seven areas of the framework (EPOSTL) in order to explore beginning language teachers' beliefs of teaching readiness. It was adapted because some of the descriptors from the original document (EPOSTL) were excluded as they were beyond the scope of the current study. In addition, the language was simplified so that the questions could be easily comprehended by the sample. The questionnaire is a Point 5 Likert scale with closed ended statements ranging from strongly agree SA, agree A, neutral $\mathrm{U}$, disagree $\mathrm{D}$, and strongly disagree SD. Likert scale questions are one of the most commonly used scales for examining self-reported perceptions and attitudes.. After adapting the questionnaire, a pilot study was done in order to find out the validity and the reliability of the tool. A randomly chosen group of five beginning language teachers were asked to fill the questionnaire. After the completion of the survey. Some potential misunderstandings were identified which were revised before the questionnaire was administered to the sample.

\section{FINDINGS}

\section{Context}

Teaching decisions are strongly influenced by the educational and social context in which teachers become a part of the profession. The context contains the overall aims and specific needs of learners in which the teachers are expected to cater the emotional needs of the learners. Language teachers have to play a number of roles. They need to critically assess their teaching on the basis of experience, learner feedback and learning outcomes and adapt it accordingly and moreover they must prepared enough to recognise the resource limitations existent at their school and adapt their teaching accordingly. 


\section{Methodology}

Methodology is the application of learning objectives through various teaching processes. It is based on the principles developing from the theories of language description, language learning and the use of language. Teachers may apply specific teaching techniques to support the learning the aspects of the language system, such as speaking, listening, writing, reading, grammar and vocabulary. For the speaking and listening skills, the teachers need to be prepared for creating a supportive atmosphere that invites learners to take part in speaking activities and help learners identify the features of spoken language. They are required to select a range of meaningful writing activities to help learners produce text clearly. For the grammar and a variety of activities can also be used in order to help students learn vocabulary.

\section{Resources}

This section deals with the variety of sources teachers are required to draw on in the process of locating, selecting and producing texts, tasks and reference materials useful for their learners. Teachers are required to select those texts and language activities from course books which are appropriate for their learners.

\section{Lesson Planning}

Lessons planning deals with the didactic questions of why, what and how: why the teachers need to focus on the specific learning objectives and how to use learning material. The most important thing for the teachers is to know that which activities should be selected. The decision is dependent on the requirements of the curriculum and on the specific groups of learners. Teachers are required to know the curriculum and how to transform its aspects into clear aims and the objectives which can be understood by all the learners of the classroom. When the teachers plan a lesson, their knowledge related to a wide scope of methodology, resources and learner activities are as important as knowledge of the individual learner's abilities.

\section{Conducting a Lesson}

The section of conducting a lesson focuses on what teachers need to do in the classrooms and on the skills that are required. The first of these is the application of a lesson plan. This takes into account the ability to start lesson in an engaging, coherent and flexible way. The teachers need to present language content in a way which is appropriate for individuals and specific groups of learners. This section also identifies teachers' interactions as significantly important with the class during the teaching and learning. Consideration is given to the initial settling down and to keeping attention, as well as to boosting learner creativities and responses, and to working with and being receptive to a range of learning styles and learning strategies within interaction. It is the ability of the teachers to manage classroom events, organize different ways of working and use a range of resources. Then it focuses on use of the target language in 
class by the teachers. The teachers have to make decisions when it is necessary to use the target language in terms of learning and to help learners understand what is said or written during the lesson.

\section{Independent Learning}

Language learning is also a matter of learning individually, collaborating with peers and as well as learning independently under the supervision of the teacher. This provides every individual learner or groups of learners an opportunity to take charge of aspects of their own learning processes in order to reach their full potential. As far as learner autonomy is concerned, taking charge means helping learners in setting specific objectives, choosing appropriate content, activities, and forms of assessment. Autonomous learning is an essential part of learning English as foreign languages, not an additional method of teaching. As teachers, they need to know how to structure the lessons and design appropriate tasks which assist different level of learners in their choices and their ability to reflect on and assess their learning themselves. Homework provides valuable additions to language learning at school. It is the responsibility of the teacher to offer real learning opportunities for their learners beyond the classroom.

\section{Assessment of Learning}

This category deals with the range of choices which the teachers have to make when they assess learning processes or the outcomes of learning. Such choices relate to the general questions such as what to assess, when to assess and how to assess. Assessment of learners consists of tests and examinations, which take a print of the learners' performance. They may focus on learners' knowledge of language and their ability to use language in realistic contexts. Teachers need to consider how useable a particular test can be in terms of the aims and objectives of learning a language while selecting. It is also important to take into account how practical a test is to design, use and how to avoid a washback effect, which may influence teaching adversely. Assessment procedures are mainly used for the purpose of summative or for formative evaluation, for example, to provide information about the learners' strengths and weaknesses and to help the teachers to plan further work. The teachers need to use assessment procedures which are appropriate for different learners in order to monitor learners' progress using reports, checklists and grades. Teachers can also encourage their learners to set personal targets and assess their own performances by engaging them in peer and self-assessments.

\section{RESULTS}

The questionnaire was administered to the beginning English language teachers on their locations. The statistical analysis indicates the percentages and frequencies of the participants' responses related to their teaching readiness. 


\begin{tabular}{lccccc}
\hline Table 1: & \multicolumn{1}{c}{ Teaching Context } & & & & \\
\hline \multicolumn{1}{c}{ Statements } & $\mathbf{1}$ & $\mathbf{2}$ & $\mathbf{3}$ & $\mathbf{4}$ & $\mathbf{5}$ \\
\hline $\begin{array}{l}\text { I consider the emotional needs of } \\
\text { the learners }\end{array}$ & - & - & - & $46.7 \%$ & $53.3 \%$ \\
$\begin{array}{l}\text { I evaluate my teaching on the basis } \\
\text { of learning outcomes }\end{array}$ & $-3.3 \%$ & $6.7 \%$ & $40 \%$ & $50 \%$ \\
$\begin{array}{l}\text { I can adjust to the resource limit in } \\
\text { my school }\end{array}$ & $-3.3 \%$ & $3.3 \%$ & $60 \%$ & $33.3 \%$ \\
\hline
\end{tabular}

In the category of teaching context, the table 1 show the results that $53.3 \%$ of the respondents strongly agreed while $46.7 \%$ of them agreed on taking into account the affective needs of the learners, indicating that learners' emotional needs were taken into account by the beginning language teachers. On evaluating their teaching on the basis of learning outcomes, $50 \%$ of the respondents strongly agreed while $40 \%$ agreed with $6.7 \%$ remaining neutral and $3.3 \%$ disagreed suggesting the beginners were able to assess their teaching on the basis of learning outcomes and adapt their teaching accordingly. The perceptions of the teachers on adjusting their teaching to the limit of the resources in their school, $60 \%$ of the respondents agreed while $33.3 \%$ respondents strongly agreed indicating that they were ready to adapt their teaching according to the resources available in their schools with a small percentage remaining neutral or disagreeing with working within the resources provided whereas $3.3 \%$ disagreed.

Table 2: $\quad$ Methodology

\begin{tabular}{|c|c|c|c|c|c|}
\hline Statements & 1 & 2 & 3 & 4 & 5 \\
\hline $\begin{array}{l}\text { I can make helpful setting for } \\
\text { different ability students to } \\
\text { participate in speaking activities. }\end{array}$ & $26.7 \%$ & $60 \%$ & - & $10 \%$ & $3.3 \%$ \\
\hline $\begin{array}{l}\text { I can use different methods to help } \\
\text { students to write text clearly. }\end{array}$ & $46.7 \%$ & $26.7 \%$ & $3.3 \%$ & $13.3 \%$ & $10 \%$ \\
\hline $\begin{array}{l}\text { I can plan activities to help learners } \\
\text { understand forms of speech. }\end{array}$ & $33.3 \%$ & $56.7 \%$ & - & $3.3 \%$ & $6.7 \%$ \\
\hline $\begin{array}{l}\text { I can use activities to develop } \\
\text { reading strategies }\end{array}$ & $30 \%$ & $43.3 \%$ & $6.7 \%$ & $16.7 \%$ & $3.3 \%$ \\
\hline $\begin{array}{l}\text { I can use grammar activities to } \\
\text { encourage speaking and writing }\end{array}$ & $50 \%$ & $23.3 \%$ & - & $10 \%$ & $16.7 \%$ \\
\hline $\begin{array}{l}\text { I can apply activities to help } \\
\text { students learn new words }\end{array}$ & - & $13.3 \%$ & 6.79 & $26.7 \%$ & $53.3 \%$ \\
\hline
\end{tabular}

For the category of methodology, the table 2 shows the results that $60 \%$ of the teachers disagreed and $26.7 \%$ strongly disagreed with only $13 \%$ being agreed, indicating that beginning language teachers were not able create supportive activities for the different 
levels of learners to develop speaking skills. On using different methods to help students writing clear text, $46.7 \%$ and $26.7 \%$ strongly disagreed and disagreed which indicates that the beginners were not to using variety of techniques to help learners produce text cohesively and coherently. Participants' responses with regard to the statement on using activities to help learners understand forms of speech, the results show that $56.7 \%$ of the beginning language teachers disagreed and $33.3 \%$ strongly disagreed with $10 \%$ being agreed highlighting that beginner teachers were not ready in terms of using different techniques to assist learners in interpreting the features of the spoken language. Beginning language teachers' perceptions of applying various activities to develop reading strategies according to the purpose of reading show that $43.3 \%$ of them disagreed and $30 \%$ strongly disagreed with $6.7 \%$ remaining neutral and $16.7 \%$ disagreed, suggesting that they were not using different reading strategies in their classes to enhance learners' reading skills.

Teachers' beliefs about selecting grammatical activities to encourage spoken and written communication show that 50\% strongly disagreed and $23.3 \%$ disagreed with $10 \%$ being strongly agreed and $13.3 \%$ agreed highlighting that beginning language teachers were not ready when it comes to using diffident grammatical activities to enhance learners' speaking and writing skills. The perceptions of the beginning language teachers on applying various activities to learn vocabulary show that 53.3\% teachers agreed strongly and $26.7 \%$ agreed with $20 \%$ being disagreed. It highlights that beginners were using activities which help students to learn new vocabulary items. In response to the statement on creating opportunities for learners to use English language out of the class, $60 \%$ of the teachers strongly disagreed and $23.3 \%$ disagreed with $13.3 \%$ remaining neutral which suggests that beginning language teachers were not providing learners the opportunities to use English language out of the classroom.

Table 3: $\quad$ Lesson Plan Development

\begin{tabular}{lccccc}
\hline \multicolumn{1}{c}{ Statements } & $\mathbf{1}$ & $\mathbf{2}$ & $\mathbf{3}$ & $\mathbf{4}$ & $\mathbf{5}$ \\
\hline $\begin{array}{l}\text { I have clear objectives for the } \\
\text { different student levels while }\end{array}$ & $16.7 \%$ & $53.3 \%$ & $3.3 \%$ & $10 \%$ & $16.7 \%$ \\
planning lesson. & & & & & \\
$\begin{array}{l}\text { I can plan learner presentations } \\
\text { for the lesson. }\end{array}$ & $23.3 \%$ & $50 \%$ & - & $20 \%$ & $6.7 \%$ \\
$\begin{array}{l}\text { I can select language activities } \\
\text { from books suitable for my }\end{array}$ & & & & & \\
students' interest.
\end{tabular}

The table 3 shows that $70 \%$ of the teachers disagreed on planning lesson according to the different learner styles indicating that they do not have clear objectives when they plan lesson for the heterogeneous classroom. With regard to planning learner 
presentations for the lesson, $73 \%$ of the participants disagreed, demonstrating that they could not manage to plan activities like presentations for the lesson. On choosing appropriate language activities from the course books for their learners, $70 \%$ of respondents indicated disagreement, signifying that majority of teachers found it difficult to select suitable activities taking into account learners' interest while planning lesson for differentiated learner styles.

Table 4: $\quad$ Conducting Lessons

\begin{tabular}{lccccc}
\hline \multicolumn{1}{c}{ Statements } & $\mathbf{1}$ & $\mathbf{2}$ & $\mathbf{3}$ & $\mathbf{4}$ & $\mathbf{5}$ \\
\hline $\begin{array}{l}\text { I can present lesson content } 73.3 \% \\
\text { that is understood by the }\end{array}$ & $23.3 \%$ & - & $3.3 \%$ & - \\
$\begin{array}{l}\text { Students } \\
\begin{array}{l}\text { I can keep the learners engaged } 63.3 \% \\
\text { during a lesson }\end{array}\end{array}$ & $20 \%$ & - & $10 \%$ & $6.7 \%$ \\
$\begin{array}{l}\text { I can manage the classroom } 23.3 \% \\
\text { environment during the lesson. }\end{array}$ & $50 \%$ & $6.7 \%$ & $6.7 \%$ & $13.3 \%$ \\
\hline
\end{tabular}

In table 4, the results show that majority (97\%) of the respondents disagreed on presenting appropriate lesson content for the learners, suggesting that it appeared to be difficult for the respondents to deliver their lesson content in a way that could be understood by the mixed ability learners sitting in the classroom. With regard to keeping learners engaged during the lesson, $83.3 \%$ of them showed disagreement, highlights that majority of them are found it challenging to make interaction and gain learners' attention during the lesson delivery. On managing the classroom environment during the lesson, $83 \%$ of the respondents were in disagreement, suggesting it unsettled majority of the respondents in managing the entire class while delivering the lesson.

Table 5: $\quad$ Independent Learning

\begin{tabular}{lllll}
\hline \multicolumn{1}{c}{$\mathbf{1}$} & $\mathbf{2}$ & $\mathbf{3}$ & $\mathbf{4}$ & $\mathbf{5}$ \\
\hline $\begin{array}{l}\text { I can help students in choosing } 26.7 \% \\
\text { tasks according to their needs. }\end{array}$ & $53.3 \%$ & - & $16.7 \%$ & $3.3 \%$ \\
$\begin{array}{l}\text { I can assign work that can be } \\
\text { done by students at home. }\end{array}$ & $16.7 \%$ & $6.7 \%$ & $13.3 \%$ & $43.3 \%$ \\
\hline
\end{tabular}

In the table 5, the results indicate that $80 \%$ respondents found it challenging to assist learners in selecting tasks taking into account learners' ability. While, the participants' responses on selecting suitable tasks to be carried out by the learners at home indicate that majority of the participants (56\%) managed to assist their learners to carry out learning tasks at their homes whereas $36.7 \%$ of the respondents indicated disagreement to the statement. 


\begin{tabular}{|c|c|c|c|c|c|}
\hline Assessment of & earnin & & & & \\
\hline Statements & 1 & 2 & 3 & 4 & 5 \\
\hline $\begin{array}{l}\text { I can use appropriate } \\
\text { assessment procedures for } \\
\text { the learners }\end{array}$ & $30 \%$ & $46.7 \%$ & $3.3 \%$ & $6.7 \%$ & $13.3 \%$ \\
\hline $\begin{array}{l}\text { I can identify weak areas for } \\
\text { improvement in students' } \\
\text { performance. }\end{array}$ & - & - & $6.7 \%$ & $33.3 \%$ & $60 \%$ \\
\hline $\begin{array}{l}\text { I provide feedback to } \\
\text { students on their errors. }\end{array}$ & 26.7 & 13.3 & - & $16.7 \%$ & $43.3 \%$ \\
\hline
\end{tabular}

The table 6 shows that $77.7 \%$ of the participants disagreed on using suitable evaluation procedures to monitor learners' progress, highlighting that majority of them relied on using were not ready in terms of selecting suitable assessment tools for variety of learners in the classroom. The responses of the beginning language teachers on identifying areas for improvement in learners' performance show that $93.3 \%$ of them are in agreement. On giving feedback to learners concerning their errors, $60 \%$ of the respondents indicated agreement, whereas $40 \%$ of them disagreed indicating that some of the teachers were not giving learners constructive feedback to on their deficiencies.

\section{DISCUSSION}

In response to the objective of the study, exploring the beginning teachers' perceptions of their readiness for teaching English language, the findings revealed that beginner teachers were unable to apply methods for teaching the different English language skills such as speaking, listening, writing and reading as most of them had no familiarity with using meaningful tasks to encourage learners of differing capabilities to actively participate. They lacked the assurance to use techniques to assist learners in producing coherent and cohesive written texts and felt unprepared in terms of applying techniques to help learners interpret essential features of the spoken language, signifying that beginning teachers' confidence of selecting a variety of meaningful activities to help learners become aware of and use appropriate language was lacking. Teachers' obvious avoidance of using grammar activities to encourage spoken and written communication was also noticeable. These findings are in line with Chacon (2005) findings where he drew attention to the lack of the beginning teachers' readiness to apply variety of techniques related to grammar, writing, speaking and listening and reading.

The findings also revealed that most beginning teachers, overwhelmed by the less than average reading levels had strong misgivings about their students' ability to read and analyze texts, and hence relied on basic textbook content to convey information. That showed their lack of experience in setting specific objectives for the different learners' 
levels. Their ability in terms of structuring lessons in a coherent way and selecting a variety of organizational forms such as individual, pair, group work does not seem to be evident in their practices. These outcomes concur with Hussain et al. (2018) concluding that the beginner teachers do not have clear ideas about planning their lessons.

Majority of the beginning language teachers were not prepared when it comes to presenting lesson content in a way which could be appropriate for the slow and specific groups of learners. A class lecture is considered to be the most efficient means of introducing content and ensuring smooth changeover between tasks and activities for the individuals, groups and the entire class during the lesson delivery. The results find support with Fantilli and McDougall (2009), who discovered that beginners lack skills in organizing appropriate lesson content catering different learners' abilities.

The perceptions of the beginning language teachers revealed that it was hard for them to maximize the attention of the learners while conducting lesson. Likewise, majority of the beginning teachers seemed unprepared in terms of taking on different roles as resource person, mediator, supervisor according to the requirements of the activity and learners' needs while conducting a lesson.

Independent learning is an essential part of learning the languages, however the teachers' ability to enable learners to choose tasks according to their needs proved challenging for them and evaluating and selecting a variety of activities which could assist their students in developing specific study skills and learning strategies appeared a daunting task. The findings of the study revealed that majority of the beginning teachers were unable to select varied assessment procedures suitable for the learners, indicating that they lacked preparation to best assess the learners' work and progress.

\section{CONCLUSION}

Being ready to take over the duties of teaching profession at the beginning of the career seems to be very important as it reduces the risk of failure that may affect their teaching profession. The current study concludes that the beginning language teachers did not seem to be adequately prepared for their teaching profession as the opening period of teaching is usually challenging for teachers. Most of the beginning teachers perceived similar challenges, regardless of context and setting. It appears that in all instances, their insufficient preparation directly shaped the instructional choices seemingly endorsing the beginning teachers' decisions of choosing the traditional chalk and board strategies and adherent to textbooks.

The findings highlighted several factors that appeared to overrule the pedagogical strategies they learned in their induction training. The beginning language teachers 
were not prepared in terms of applying teaching methodologies to teach different language skills, which include, speaking, listening, writing, reading, grammar and vocabulary. The beginner teachers were not satisfactorily prepared enough to plan lessons primarily because they were not able to set specific lesson objectives considering differentiated ability levels and needs of the learners. Their ability to present content, appropriate for the different learner was also absent during the lesson delivery. Moreover, their choices of assessing learners' performance were not innovative, demonstrating that they preferred using traditional methods. However, it can be concluded that beginners did not acquire skills and the lack of such skills not only obstructs their attempts of creativity but also hinders their professional development as teachers. For the teacher training, it serves as the feedback that the structure of their program should focus on enabling novices in applying a variety of methodologies for teaching different language skills, planning lesson for the heterogeneous class, conducting lesson and evaluating learner performance.

The study was limited to explore the beginners' beliefs of their readiness whose experience ranged from 1-4 years public sector schools in Punjab. Hence results cannot be generalized. The results may vary if the similar study is conducted in different contexts other than the Punjab province.

\section{RECOMMENDATIONS}

1. It is recommended that further studies can be done using mixed method to teachers' readiness.

2. The future research can select a large sample for more generalized results.

3. Future research can be conducted in the different context to extend the scope of results.

\section{REFERENCES}

Alharbi, A. (2011). The development and implementation of a CPD programme for newly qualified teachers in Saudi Arabia (Doctoral dissertation, University of Southampton).

Al-Hazmi, S. (2003). EFL teacher preparation programs in Saudi Arabia: Trends and challenges. Tesol Quarterly, 37(2), 341-344.

Baker, P. H. (2003). The role of self-efficacy in teacher readiness for differentiating discipline in classroom settings.

Bandura, A. (1993). Perceived self-efficacy in cognitive development and functioning. Educational psychologist, 28(2), 117-148.

Belatrech, H. S. K. (2018). Novice EFL Teachers' Challenges in Mostaganem Rural Areas. Social Sciences, 7(3), 125-132.

Ben-Peretz, M. (2001). The impossible role of teacher educators in a changing world. Journal 

of teacher education, 52(1), 48-56.

Brandenburg, R. T. (2008). Powerful pedagogy: Self-study of a teacher educator's practice (Vol. 6). Springer Science \& Business Media.

Carre, C. (1993). The first year of teaching. In N. Bennett \& C. Carre (Eds.), Learning to teach (pp. 191-211).

Caspersen, J., \& Raaen, F. D. (2014). Novice teachers and how they cope. Teachers and Teaching, 20(2), 189-211.

Chacón, C. T. (2005). Teachers' perceived efficacy among English as a foreign language teachers in middle schools in Venezuela. Teaching and Teacher Education, 21(3), 257-272.

Darling-Hammond, L. (2003). Keeping good teachers: Why it matters, what leaders can do? Educational leadership, 60(8), 6-13.

Evertson, C. M., \& Weinstein, C. S. (Eds.). (2013). Handbook of classroom management: Research, practice, and contemporary issues. Routledge.

Fantilli, R. D., \& McDougall, D. E. (2009). A study of novice teachers: Challenges and supports in the first years. Teaching and teacher education, 25(6), 814-825.

Farrell, T. S. (2012). Novice-service language teacher development: Bridging the gap between pre-service and in-service education and development. Tesol Quarterly, 46(3), 435-449.

Farrell, T. S. (Ed.). (2009). Novice language teachers: Insights and perspectives for the first year. Equinox Pub.

Graham, A., \& Phelps, R. (2003). Being a teacher: Developing teacher identity and enhancing practice through metacognitive and reflective learning processes. Australian Journal of Teacher Education, 27(2), 11.

Haynes, L. (2011). Novice teachers' perceptions of their mentoring experiences. Lamar University-Beaumont.

Hoy, A. W., \& Spero, R. B. (2005). Changes in teacher efficacy during the early years of teaching: A comparison of four measures. Teaching and teacher education, 21(4), 343-356.

Hussain, A., Haq, N. M. \& Kousar, A. (2018). Exploring practices of Novice teachers at primary classes in private schools of Skardu, Pakistan._Journal of Applied Environmental and Biological Sciences, 8_ (7), 46-56

Kee, A. N. (2012). Feelings of preparedness among alternatively certified teachers: What is the role of program features. Journal of Teacher Education, 63(1), 23-38.

Kim, K. A., \& Roth, G. L. (2011). Novice teachers and their acquisition of work-related information. Current issues in Education, 14(1).

Meddour, M. (2017). I Am Not Ready for Teaching! EFL Graduates' challenges and Expectations of the Profession. PEOPLE: International Journal of Social Sciences, 3(3).

Ministry of Education. (2009). National Education Policy. Government of Pakistan

Newby, D. (2007). European Portfolio for Student Teachers of Languages: A reflection tool for language teacher education. Council of Europe.

Ouma, G. O., Awuor, F. M., \& Kyambo, B. (2013). E-Learning Readiness in Public Secondary Schools in Kenya. European Journal of Open, Distance and Elearning, 16(2), 97-110. 
PJER, Vol 4, Issue 1 (2021)

Exploring beginning English...

Schmidt, C. (2008). The transition from teacher education to ESL/EFL teaching in the first year for non-native English speaking teachers in Canada. Novice Language Teachers Insights and Perspectives for the First Year, 73-88.

Shafie, L. A., \& Nayan, S. (2010). The roles of university English teachers in Malaysia. Journal of Language Teaching and Research, 1(3), 262-265.

Siddiqui, S. (2007). Rethinking education in Pakistan: Perceptions, practices, and possibilities. Paramount Publishing Enterprise.

Smith, T. M., \& Ingersoll, R. M. (2004). What are the effects of induction and mentoring on beginning teacher turnover? American educational research journal, 41(3), 681-714.

Straková, Z. (2015). The perception of readiness for teaching profession: a case of pre-service trainees. Journal of language and cultural education, 3(1), 32-42. 